\title{
Morphology and distribution of some marine diatoms, family Rhizosoleniaceae, genus Proboscia, Neocalyptrella, Pseudosolenia, Guinardia, and Dactyliosolen in Korean coastal waters
}

\author{
Suk Min Yun ${ }^{1, a}$ and Jin Hwan Lee ${ }^{1, *}$ \\ ${ }^{1}$ Department of Life Science, Sangmyung University, Seoul 110-743, Korea
}

The morphology, taxonomy, and distribution of species belonging to the diatom family Rhizosoleniaceae were studied from the marine coastal waters of Korea. Rhizosolenid diatom taxa were collected at 30 sites from September 2008 to February 2010 and were analyzed by light and scanning electron microscopy. We identified 6 rhizosolenid genera, including Rhizosolenia, Proboscia, Pseudosolenia, Neocalyptrella, Guinardia, and Dactyliosolen. We describe 5 genera in this study, except Rhizosolenia. Five genera were compared in detail with congeneric species. Six genera within the family Rhizosoleniaceae were divided into two groups based on morphological diagnostic characters including valve shape, areolae pattern, the shape of external process, and girdle segments in the column. The first group had a conoidal valve and loculate areolae, which comprised Rhizosolenia, Proboscia, Pseudosolenia, and Neocalyptrella, and the second group of Guinardia and Dactyliosolen showed a flat or rounded valve and poroid areolae. Important key diagnostic characters were based on valve shape, areolae pattern on the segment, external process, position of the tube, and the valve margin. D. phuketensis was new to Korean coastal waters.

Key Words: Dactyliosolen; diatoms; distribution; Guinardia; morphology; Neocalyptrella; Proboscia; Pseudosolenia; Rhizosolenia

\section{INTRODUCTION}

Peragallo (1892) regarded the genera Dactyliosolen Castracane, Lauderia Cleve, Attheya T. West, Guinardia H. Peragallo, and Rhizosolenia Brightwell as members of Rhizosoléniées. Thereafter, Hustedt (1930) suggested that 23 marine and 4 freshwater species belonged to this family. He synonymized several species, as several earlier studies described variations of seemingly the same species.

Sundström (1986) suggested that only those species with valves bearing an external process, otaria, claspers, and copulae perforated by loculate areolae should be included in the genus Rhizosolenia. According to Sund- ström (1986), the genus Proboscia Sundström and Pseudosolenia Sundström were separated from Rhizosolenia because they have external processes. The two species of $R$. calcar-avis Schultze and $R$. alata Brightwell were subsequently transferred to Pseudosolenia calcar-avis Sundström and Proboscia alata Sundström, respectively (Sundström 1986). R. robusta Norman was also transferred to Neocalyptrella robusta Hernández-Becerril and Meave (Hernández-Becerril and Meave del Castillo 1996, 1997).

More recently, the family Rhizosoleniaceae included Neocalyptrella, Pseudosolenia, Proboscia, and Urosolenia. (c) This is an Open Access article distributed under the terms of the Creative Commons Attribution Non-Commercial License (http://creativecommons.org/licenses/by-nc/3.0/) which permits unrestricted non-commercial use, distribution, and reproduction in any medium, provided the original work is properly cited.
Received September 10, 2011, Accepted November 5, 2011

*Corresponding Author

E-mail: jhlee@smu.ac.kr

Tel: +82-2-2287-5152, Fax: +82-2-2287-0098

${ }^{a}$ Present address: Laboratory of Plankton Ecology, Korea Institute of Coastal Ecology, Inc., Bucheon 421-808, Korea 
Representatives of these genera are commonly found as solitary cells in marine environments, except Urosolenia, which is restricted to freshwater (Edlund and Stoermer 1993, Rott et al. 2006, Li et al. 2009). The genera Guinardia and Dactyliosolen have been allocated to the family Rhizosoleniaceae.

In Korea, the genera Rhizosolenia, Guinardia, and Dactyliosolen were recorded by Shim (1994). Many authors (Moon and Choi 1991, Yoon et al. 1992, Chang and Shim 1993, Kim et al. 1993, Yoon and Koh 1994, 1995) and Lee (1995) added Pseudosolenia and Proboscia to his checklist. Additional studies on the family Rhizosoleniaceae in Korea have been conducted sporadically (Yun and Lee 2010, Yun et al. 2011), but species identification, synonymies, and the phylogeny the family Rhizosoleniaceae have been insufficiently investigated. The present study provides a detailed survey of marine diatoms belonging to the genera Proboscia, Pseudosolenia, Neocalyptrella, Guinardia, and Dactyliosolen from the coastal waters of Korea. This survey provides detailed light and scanning electron microscopy illustrations and a critical review of the taxonomical and distributional data.

\section{MATERIALS AND METHODS}

Field samples were collected in Korean coastal waters from September 2008 to February 2010 (Table 1). Phytoplankton was collected using a $20 \mu \mathrm{m}$ mesh-sized net by vertical towing. Samples were immediately fixed in neutralized formalin (final concentration $4 \%$ ), glutaraldehyde (final concentration 2\%), and Lugol's solution. Organic material in the samples was removed using the methods of Hasle and Fryxell (1970) and Simonsen (1974). The materials were examined under a light microscope (Axioskop 40; Carl Zeiss, Jena, Germany), photographed with a MRc5 camera (Carl Zeiss) and a scanning electron microscope (JSM-5600LV; Jeol, Tokyo, Japan). Sizes of cells were measured using image calculation software (AxioVision AC v. 4.5; Carl Zeiss).

Terminology was from that recommended in the first report of the working Committee on Diatom Terminology (Anonymous 1975) from the third Symposium on Recent and Fossil Marine Diatoms, Kiel. Other terminology follows Ross et al. (1979), Sundström (1986), Round et al. (1990), Hernández-Becerril (1995), and Hasle and Syvertsen (1996).

\section{RESULTS}

We identified 6 rhizosolenid genera, including Rhizosolenia, Proboscia, Pseudosolenia, Neocalyptrella, Guinardia, and Dactyliosolen. We described five of these genera except Rhizosolenia. The morphological characters observed in the genera Proboscia, Neocalyptrella, Pseudosolenia, Dactyliosolen, and Guinardia species are shown in Tables 2-4. According to the system suggested by Sundström (1986), 9 phytoplanktonic diatom taxa representing 1 order, 1 suborder, 1 family, 5 genera, and 9 species were identified in this study. The systematic accounts are as follows:

Class Bacillariophyceae Haeckel 1878

Order Centrales Hustedt 1930

Suborder Rhizosoleniineae Simonsen 1979

Family Rhizosoleniaceae De Toni 1890

Genus Proboscia Sundström 1986

Proboscia alata (Brightwell) Sundström 1986

Proboscia indica (H. Peragallo)

Hernández-Becerril 1995

Genus Neocalyptrella (Norman)

Hernández-Becerril \& Meave 1996

Neocalyptrella robusta Hernández-

Becerril \& Meave 1996

Genus Pseudosolenia Sundström 1986

Pseudosolenia calcar-avis (Schultze)

Sundström 1986

Genus Guinardia H. Peragallo 1892

Guinardia delicatula (Cleve) Hasle 1995

Guinardia flaccida (Castracane)

H. Peragallo 1892

Guinardia striata (Stolterforth) Hasle 1995

Genus Dactyliosolen Castracane 1886

Dactyliosolen fragilissimus (Bergon)

Hasle 1995

Dactyliosolen phuketensis (Sundström)

Hasle 1995

\section{Proboscia alata (Brightwell) Sundström 1986}

(Fig. 1, A-H)

Brightwell 1858, p. 95, Pl. 5, Fig. 8; Peragallo 1892, p. 115, Pl. 18, Figs 11-20; Hustedt 1920, Pl. 317; Hustedt 1930, p. 600, Fig. 345; Cupp 1943, p. 90, Fig. 52A \& B; Okuno 1952, p. 353, Pl. 2, Figs 5 \& 6; Okuno 1960, p. 310, Pl. 1, Fig. 1; Hendey 1964, p. 146, Pl. 2, Fig. 2; Drebes 1974, p. 57, Fig. 39c \& d; Navarro 1981, p. 430, Figs 33 \& 34 as R. alata; Sundström 1986, p. 99, Figs 258-266; Jordan et al. 1991, p. 65, Figs 1-9; Takahashi et al. 1994, p. 413, Figs 2-7; Hernández-Becerril 1995, p. 252, Figs 2-4; Hasle and 
Syvertsen 1996, p. 159, Pl. 30; Sunesen and Sar 2007, p. 639, Figs 82-88 \& 98.

Synonyms. Rhizosolenia alata Brightwell 1858, Rhizosolenia alata f. gracillima (Cleve) Gran 1905.

Cells are solitary or in pairs, narrow cylindrical, bilaterally symmetrical, 3.3-13.3 $\mu \mathrm{m}$ in diameter, 270.0-485.7 $\mu \mathrm{m}$ long. Valve is sub-conoidal, the ventral part longer than the dorsal part and proboscis structure is slightly curved, tapering towards the apical part of the valve, circular in cross section, 15.0-30.0 $\mu \mathrm{m}$ long. Apical surface of the proboscis is composed of variously sized spinules. Number of spinules is 7-16, 0.1-0.4 $\mu \mathrm{m}$ long. Contiguous area is convex towards the valve surface, distally limited by asymmetric claspers. The valve areolae are rounded, 52-90 in $10 \mu \mathrm{m}$, arranged in longitudinal striae, converg- ing towards the apex. Girdle segment areolae are loculate, arranged in columns, with the external velum perforated by central pores, and internal circular foramina, 25-62 in $10 \mu \mathrm{m}$. Interlocular pores are commonly surrounded by six loculi. Segment horizontal axis and perpendicular axis are 3.3-13.3 and 10.0-26.7 $\mu \mathrm{m}$ long, respectively.

Distribution. Proboscia alata has frequently been reported in the Argentine Sea (Ferrario and Galávan 1989 as $R$. alata and $R$. alata f. gracillima). During this study, $P$. alata was frequently observed in September 2008 and June 2009 at the Wolsung coast, Jeju Island, and the Korea Strait.

Remarks. Sundström (1986) did not share the biogeographical limits of $P$. alata because synonyms were used for probably all taxa included in the genus. The specific

Table 1. Sampling sites for the genera Proboscia, Neocalyptrella, Pseudosolenia, Guinardia, and Dactyliosolen of the family Rhizosoleniaceae

\begin{tabular}{|c|c|c|c|c|}
\hline Location & Latitude (N) & Longitude (E) & Sampling date & Species \\
\hline Korea Strait & $34^{\circ} 44.965$ & $128^{\circ} 50.083$ & Sep 10, 2008 & Proboscia alata \\
\hline Wolsung coast & $35^{\circ} 43.836$ & $129^{\circ} 29.225$ & May 20, 2009 & \\
\hline Jeju Is. & $33^{\circ} 33.442$ & $126^{\circ} 47.706$ & Sep 15, 2009 & \\
\hline Yellow Sea & $35^{\circ} 30.521$ & $124^{\circ} 10.773$ & Sep 22, 2008 & P. indica \\
\hline Daecheon Harbor & $36^{\circ} 18.203$ & $126^{\circ} 30.925$ & May 3, 2009 & \\
\hline Geoje Is. & $34^{\circ} 59.588$ & $128^{\circ} 40.519$ & Jun 25, 2009 & \\
\hline Daebu Is. & $37^{\circ} 17.852$ & $126^{\circ} 34.351$ & Jul 25, 2009 & \\
\hline Yangyang coast & $38^{\circ} 07.411$ & $128^{\circ} 37.961$ & Oct 15, 2009 & \\
\hline Yellow Sea & $35^{\circ} 30.521$ & $124^{\circ} 10.773$ & Sep 22, 2008 & Neocalyptrella robusta \\
\hline Korea Strait & $34^{\circ} 37.629$ & $128^{\circ} 44.887$ & Feb 10, 2009 & \\
\hline Wolsung coast & $35^{\circ} 43.836$ & $129^{\circ} 29.225$ & May 20, 2009 & \\
\hline Geoje Is. & $34^{\circ} 59.588$ & $128^{\circ} 40.519$ & Jun 25, 2009 & \\
\hline Yellow Sea & $35^{\circ} 30.521$ & $124^{\circ} 10.773$ & Sep 22, 2008 & Pseudosolenia calcar-avis \\
\hline Jeju Is. & $33^{\circ} 12.578$ & $126^{\circ} 15.557$ & Sep 15, 2009 & \\
\hline Jeju Is. & $33^{\circ} 18.572$ & $126^{\circ} 09.876$ & Sep 15, 2009 & \\
\hline Sacheon coast & $37^{\circ} 20.731$ & $126^{\circ} 41.181$ & Jul 25, 2009 & Guinardia delicatula \\
\hline Incheon coast & $37^{\circ} 22.125$ & $126^{\circ} 33.193$ & Aug 17, 2009 & \\
\hline Mokpo Bay & $34^{\circ} 46.843$ & $126^{\circ} 22.884$ & Jan 12,2010 & \\
\hline Yellow Sea & $35^{\circ} 30.521$ & $124^{\circ} 10.773$ & Sep 22, 2008 & G. flaccida \\
\hline Geoje Is. & $34^{\circ} 59.588$ & $128^{\circ} 40.519$ & Jun 25, 2009 & \\
\hline Namhae Br. & $34^{\circ} 54.986$ & $128^{\circ} 01.956$ & Jul 19, 2009 & \\
\hline Sacheon coast & $35^{\circ} 00.276$ & $128^{\circ} 01.195$ & Aug 6, 2009 & \\
\hline Tongyeong coast & $34^{\circ} 54.558$ & $128^{\circ} 26.491$ & Aug 7, 2010 & \\
\hline Incheon coast & $37^{\circ} 22.125$ & $126^{\circ} 33.193$ & Aug 17, 2009 & \\
\hline Namhae Br. & $34^{\circ} 54.986$ & $128^{\circ} 01.956$ & Jul 19, 2009 & G. striata \\
\hline Daebu Is. & $37^{\circ} 17.852$ & $126^{\circ} 34.351$ & Jul 25, 2009 & \\
\hline Incheon coast & $37^{\circ} 22.125$ & $126^{\circ} 33.193$ & Aug 17, 2009 & \\
\hline Yeongdeok coast & $36^{\circ} 36.038$ & $129^{\circ} 24.573$ & Oct 16,2009 & \\
\hline Goseong coast & $38^{\circ} 16.205$ & $128^{\circ} 33.438$ & Feb 20, 2010 & Dactyliosolen fragilissimus \\
\hline Geoje Is. & $34^{\circ} 59.588$ & $128^{\circ} 40.519$ & Jun 25, 2009 & D. phuketensis \\
\hline Sacheon coast & $35^{\circ} 00.276$ & $128^{\circ} 01.195$ & Aug 6, 2009 & \\
\hline Tongyeong coast & $34^{\circ} 54.545$ & $128^{\circ} 18.851$ & Aug 6, 2009 & \\
\hline Yellow Sea & $35^{\circ} 30.521$ & $124^{\circ} 10.773$ & Sep 22, 2008 & \\
\hline Yeongduk coast & $36^{\circ} 36.038$ & $129^{\circ} 24.573$ & Oct 16, 2009 & \\
\hline
\end{tabular}



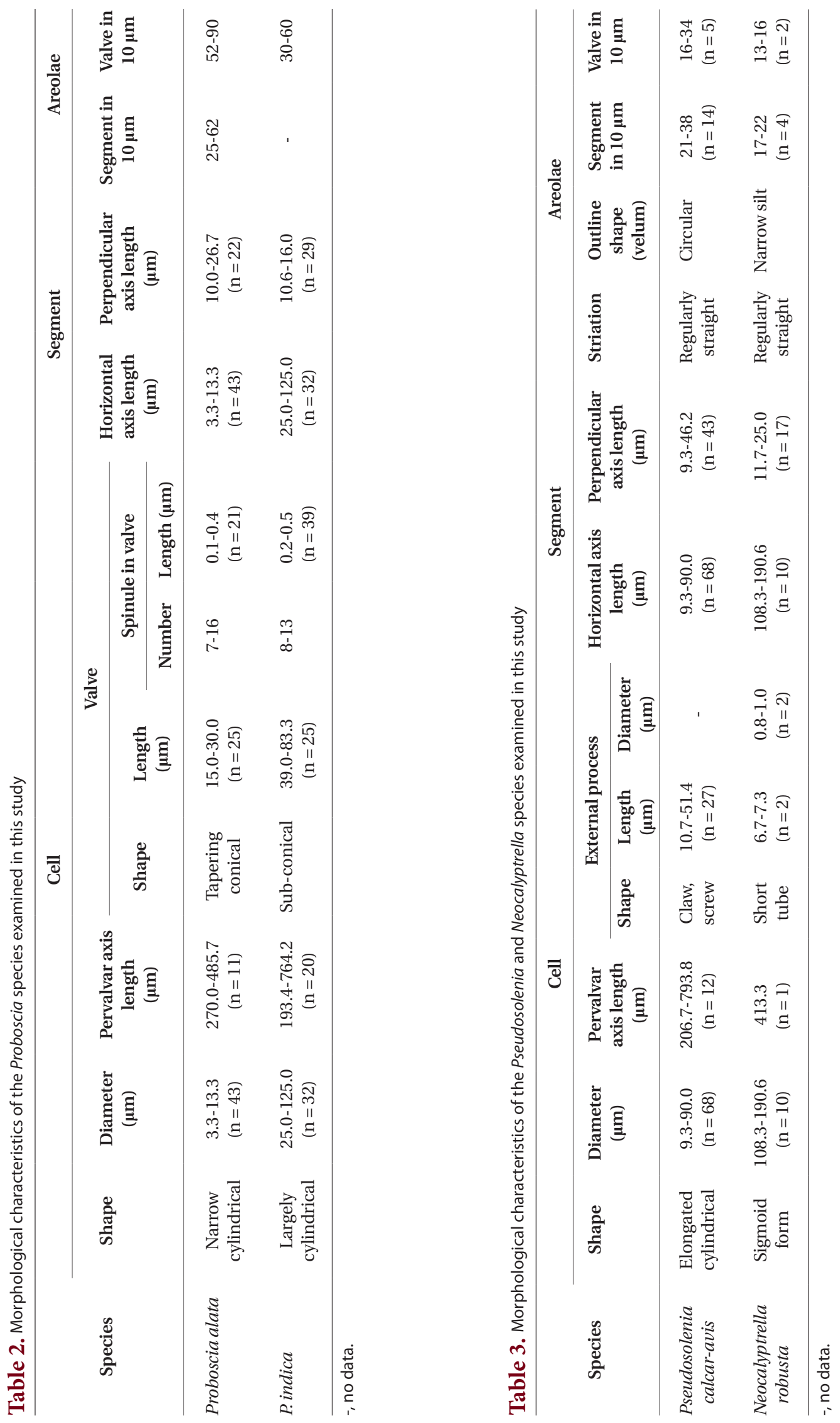

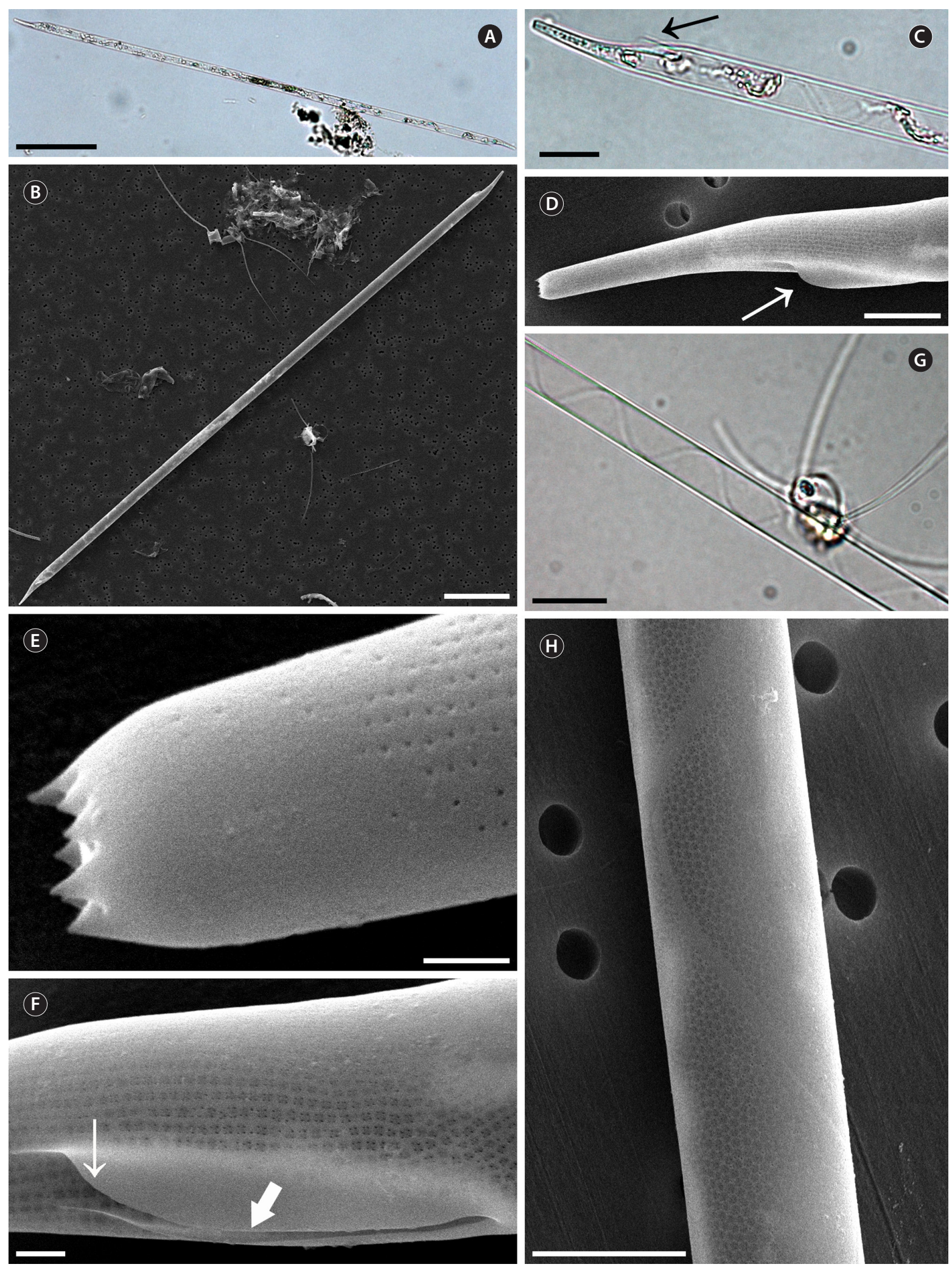

Fig. 1. Proboscia alata. (A) A complete cell, light microscopy (LM). (B) A complete cell, scanning electron microcopy (SEM). (C) Apical part of the valve, noticeable clasper (arrow), LM. (D) Apical part of valve, noticeable clasper (arrow), SEM. (E) Details of proboscis structure, varied spinule size, SEM. (F) Details of clasper (arrow) and contiguous area, SEM. (G) Girdle segments, LM. (H) Girdle segments, SEM. Scale bars represent: A \& B, $50 \mu \mathrm{m} ; \mathrm{C}, 20 \mu \mathrm{m} ; \mathrm{D} \& \mathrm{H}, 5 \mu \mathrm{m} ; \mathrm{E}, 0.5 \mu \mathrm{m} ; \mathrm{F}, 1 \mu \mathrm{m} ; \mathrm{G}, 10 \mu \mathrm{m}$. 
Table 4. Morphological characteristics of the Dactylisolen and Guinardia species examined in this study

\begin{tabular}{|c|c|c|c|c|c|c|c|}
\hline \multirow{3}{*}{ Species } & \multicolumn{5}{|c|}{ Cell } & \multicolumn{2}{|c|}{ Segment } \\
\hline & \multirow[t]{2}{*}{ Shape } & \multirow{2}{*}{$\begin{array}{l}\text { Diameter } \\
(\mu \mathrm{m})\end{array}$} & \multirow{2}{*}{$\begin{array}{l}\text { Pervalvar } \\
\text { axis length } \\
\quad(\mu \mathrm{m})\end{array}$} & \multicolumn{2}{|c|}{ External process } & \multirow{2}{*}{$\begin{array}{c}\text { Horizontal } \\
\text { axis length } \\
\quad(\mu \mathrm{m})\end{array}$} & \multirow{2}{*}{$\begin{array}{l}\text { Perpendicular } \\
\text { axis length } \\
(\mu \mathrm{m})\end{array}$} \\
\hline & & & & Shape & $\begin{array}{c}\text { Length } \\
(\mu \mathrm{m})\end{array}$ & & \\
\hline $\begin{array}{l}\text { Dactylisolen } \\
\text { fragilissimus }\end{array}$ & Straight & $\begin{array}{l}8.3-20.0 \\
(\mathrm{n}=24)\end{array}$ & $\begin{array}{r}25.0-33.4 \\
(\mathrm{n}=18)\end{array}$ & Oblique tube & $\begin{array}{l}1.1-4.3 \\
(\mathrm{n}=9)\end{array}$ & - & - \\
\hline D. phuketensis & Curved & $\begin{array}{c}10.0-20.0 \\
(\mathrm{n}=42)\end{array}$ & $\begin{array}{c}31.3-129.2 \\
(\mathrm{n}=41)\end{array}$ & Short tube & $\begin{array}{l}1.3-6.7 \\
(n=20)\end{array}$ & $\begin{array}{c}10.0-20.0 \\
(\mathrm{n}=42)\end{array}$ & $\begin{array}{l}1.3-6.6 \\
(\mathrm{n}=70)\end{array}$ \\
\hline $\begin{array}{l}\text { Guinardia } \\
\text { delicatula }\end{array}$ & Straight & $\begin{array}{l}7.9-13.2 \\
(\mathrm{n}=41)\end{array}$ & $\begin{array}{c}24.9-30.0 \\
(\mathrm{n}=21)\end{array}$ & Narrow tube & $\begin{array}{l}2.1-5.0 \\
(n=11)\end{array}$ & $\begin{array}{l}7.9-13.2 \\
(\mathrm{n}=41)\end{array}$ & - \\
\hline G. flaccida & Straight & $\begin{array}{c}23.3-42.5 \\
(\mathrm{n}=25)\end{array}$ & $\begin{array}{c}50.0-125.0 \\
(\mathrm{n}=16)\end{array}$ & Short tube & $\begin{array}{l}1.5-1.8 \\
(\mathrm{n}=4)\end{array}$ & $\begin{array}{c}23.3-42.5 \\
(n=25)\end{array}$ & $\begin{array}{l}1.9-5.0 \\
(\mathrm{n}=140)\end{array}$ \\
\hline G. striata & Curved & $\begin{array}{c}10.0-20.0 \\
(\mathrm{n}=24)\end{array}$ & $\begin{array}{c}50.0-120.0 \\
(\mathrm{n}=16)\end{array}$ & Slight hook & $\begin{array}{l}4.3-6.7 \\
(\mathrm{n}=12)\end{array}$ & $\begin{array}{c}10.0-20.0 \\
(\mathrm{n}=24)\end{array}$ & $\begin{array}{l}4.3-4.6 \\
(\mathrm{n}=2)\end{array}$ \\
\hline
\end{tabular}

,- no data.

limits of the taxa including Proboscia have been determined by many authors (Jordan and Priddle 1991, Jordan et al. 1991, Takahashi et al. 1994, Jordan and Saito 1999, Jordan and Ito 2002, Jordan and Ligowski 2004, 2006). Takahashi et al. (1994) reported that the genus contains five modern species distributed from polar to temperate regions. Jordan and Ligowski (2004) stated that $P$. alata is not cosmopolitan, because it appears to be a complex cryptic species. Some $P$. alata representatives are commonly found in polar waters. However, HernándezBecerril (1995) found that P. alata is distributed from tropical to subtropical waters.

\section{Proboscia indica (Peragallo) Hernández-Becerril emend. Jordan \& Ligowski 1995 (Fig. 2, A-F)}

Hustedt 1930, p. 602, Fig. 346; Cupp 1943, p. 93, Fig. 52C; Hendey 1964, p. 147, Pl. 2, Fig. 4; Hernández-Becerril 1995, p. 254, Figs 5 \& 6; Moreno et al. 1996, p. 15, Pl. 29, Figs 6 \& 7; Jordan and Ligowski 2004, p. 98, Pl. 4, Figs 5-7; Gómez and Souissi 2007, p. 287, Fig. 4g-h; Sunesen and Sar 2007, p. 639, Figs 89-97 \& 99.

Synonyms. Rhizosolenia indica H. Peragallo 1892, Rhizosolenia alata f. indica (Peragallo) Gran 1905.

Cells are solitary or in pairs, cylindrical, bilaterally symmetrical, 25.0-125.0 $\mu \mathrm{m}$ in diameter, 193.4-764.2 $\mu \mathrm{m}$ long. Valve is sub-conoidal, the ventral part longer than the dorsal part. Proboscis structure is strongly curved, tapered towards the apical part in the valve, circular in cross section, 39.0-83.3 $\mu \mathrm{m}$ long. Apical surface of the proboscis is composed of varied sized spinules and the slit is pore shape situated below the apex. Spinule number is 8-13 and 0.2-0.5 $\mu \mathrm{m}$ long. Contiguous area is convex towards the valve surface, distally limited by asymmetric claspers. The valve areolae are rounded, 30-60 in $10 \mu \mathrm{m}$, arranged in longitudinal striae, converging towards the apex. Girdle segment areolae are loculate, arranged in columns, and the external velum is perforated by central pores and internal circular foramina. Interlocular pores are commonly surrounded by four loculi. The horizontal axis of the segments is $25.0-125.0 \mu \mathrm{m}$ and the perpendicular axis is $10.6-16.0 \mu \mathrm{m}$.

Distribution. Hendey (1964) reported that $P$. indica is common in temperate and sub-tropical seas as $R$. alata var. indica. This species has been reported from Buenos Aires marine waters (Marques Da Cunha and Da Fonseca 1917, Balech 1964, 1971, 1979, Lange 1985 as R. alata var. indica). During the present study, $P$. indica was rare but distributed widely at Geoje Island, Daebu Island, Daecheon Harbor, the Yangyang coast, and the Yellow Sea from September 2008 to October 2009.

Remarks. Proboscia indica and P. alata are fairly similar species. However, $P$. indica differs from $P$. alata by the larger diameter of the frustule and valve morphology. The valve shape of $P$. indica is sub-conical, round, and tapers into a strongly curved proboscis. Additionally, the pattern of the interlocular pores also differs between the two species, similar to a feature previously described by Hasle (1975) and Takano (1990). P. indica have interlocular pores surrounded by four loculae, but the P. alata interlocular pores are surrounded by six loculae, as observed by Sundström (1986). 

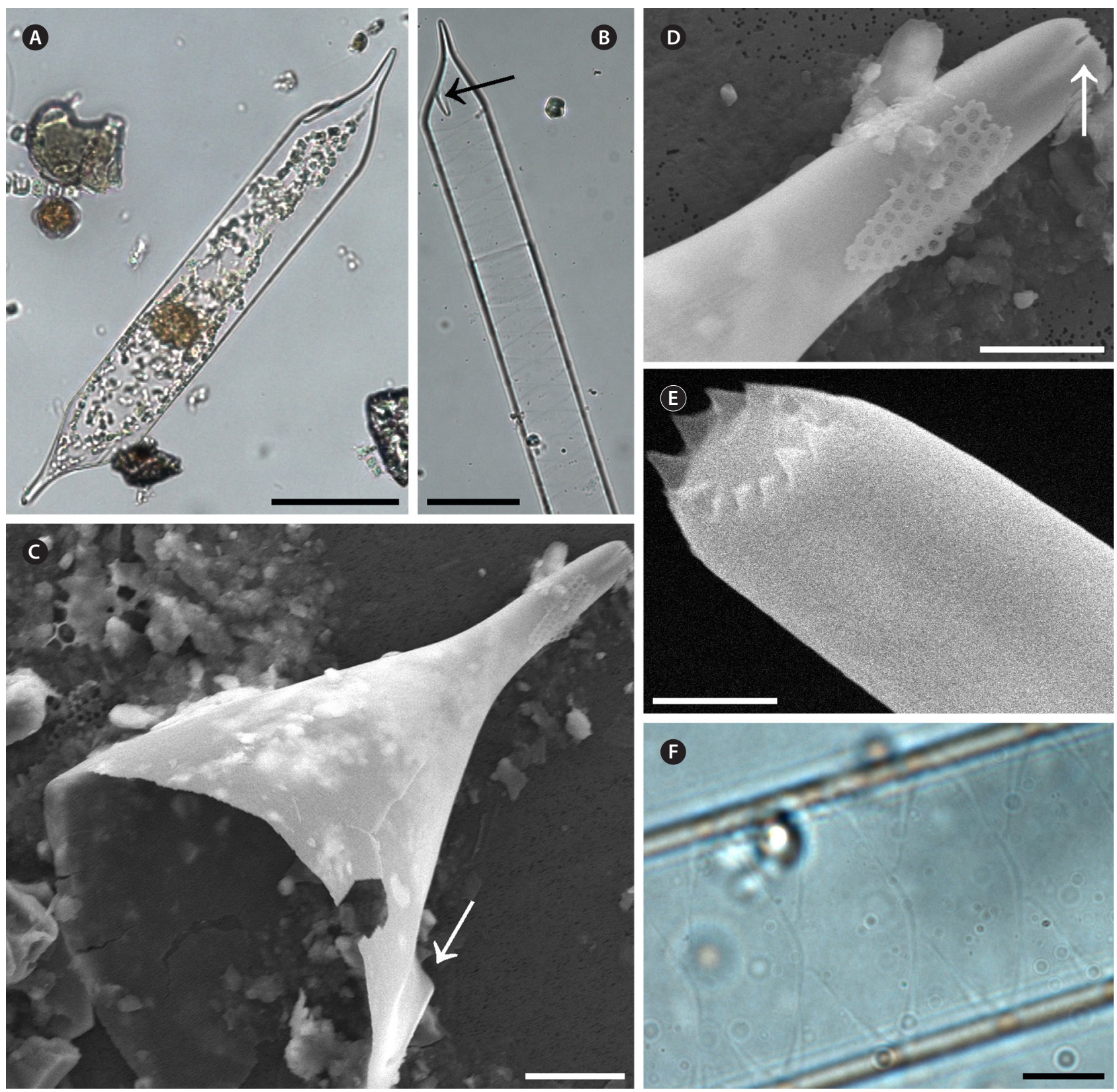

Fig. 2. Proboscia indica. (A) A complete cell, light microscopy (LM). (B) Apical part of valve, clasper (arrow), LM. (C) Apical part of the valve, clasper (arrow), scanning electron microcopy (SEM). (D) Details of Fig. 9, proboscis structure; longitudinal slit-like pore below the tip (arrow), SEM. (E) Details of the proboscis structure, varied spinule size, SEM. (F) Girdle segments, LM. Scale bars represent: A \& B, $50 \mu \mathrm{m} ; C$ \& F, $10 \mu \mathrm{m} ; \mathrm{D}, 5 \mu \mathrm{m} ; \mathrm{E}, 1 \mu \mathrm{m}$.

\section{Neocalyptrella robusta (Norman) Hernández- Becerril \& Meave 1996 (Fig. 3, A-H)}

Pritchard 1861, p. 866, Pl. 8, Fig. 42; Peragallo 1892, p. 109, Pl. 14, Fig. 1; Hustedt 1920, Pl. 320, Figs 1-3; Hustedt 1930, p. 578, Fig. 330; Cupp 1943, p. 83, Fig. 46; Okuno 1957, p. 105, Pl. 2, Fig. 1; Okuno 1968, Figs 1(6), 10A, 17 \& 18; Navarro 1981, p. 430, Figs 43 \& 45; Sundström 1986, p.
104, Figs 289 \& 290 as R. robusta; Hernández-Becerril and Meave del Castillo 1996, p. 199, Figs 1-20 as Calyptrella robusta; Hasle and Syvertsen 1996, p. 159, Pl. 30 as R. robusta; Gómez and Souissi 2007, p. 287, Fig. 4i; Sunesen and Sar 2007, p. 637, Figs 62-67.

Synonyms. Rhizosolenia robusta Norman in Pritchard 1861, Calyptrella robusta (Norman) Hernández-Becerril and Meave 1996. 

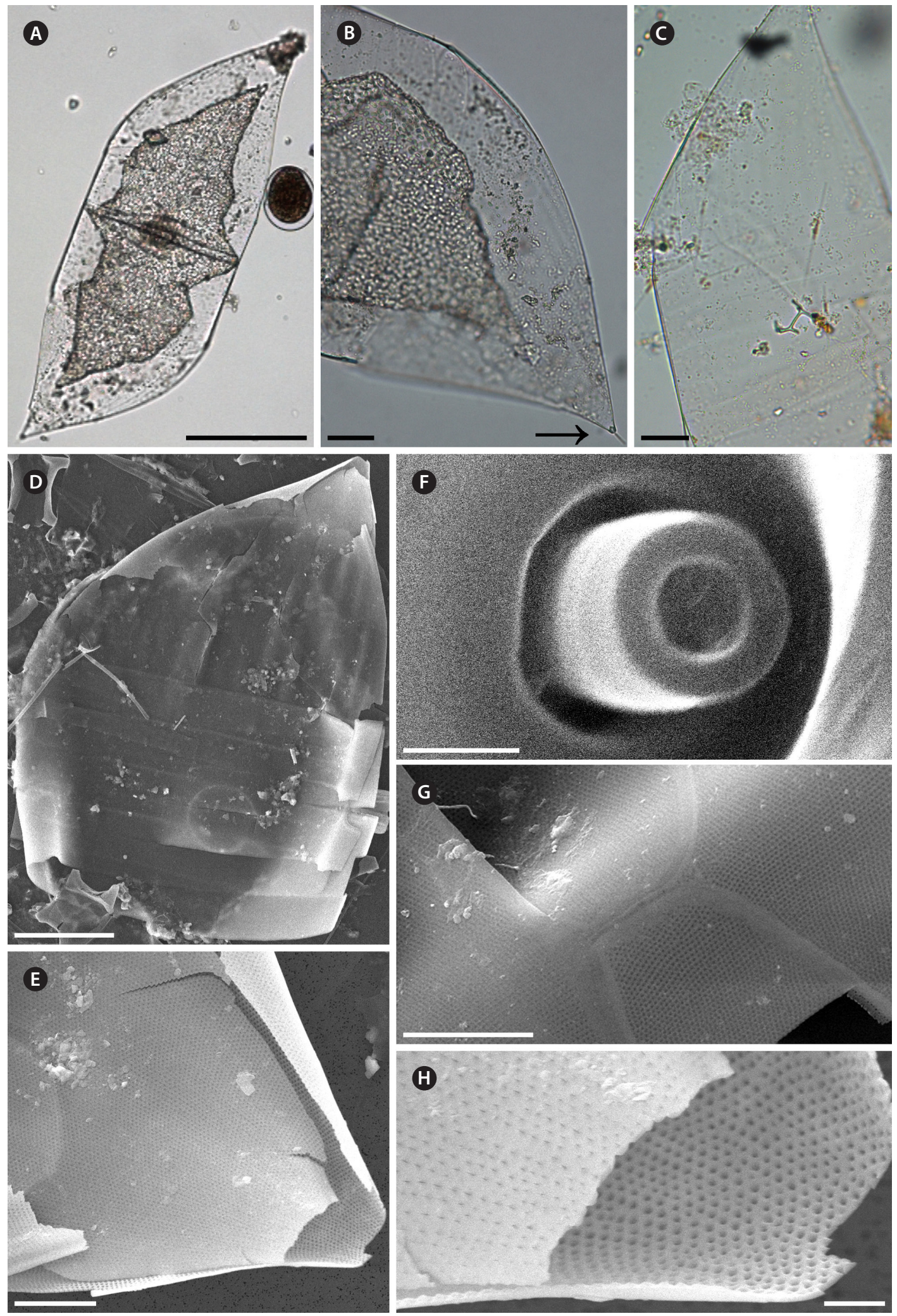

Fig. 3. Neocalyptrella robusta. (A) A complete cell, light microscopy (LM). (B) Apical part of valve, external tube at the valve apex (arrow), LM. (C) Apical part of valve, valve with part of the cingulum, LM. (D) Apical part of valve, valve with part of the cingulum, scanning electron microscopy (SEM). (E) Striation at valve apex, SEM. (F) Valve apex showing calyptra structure and external tube, SEM. (G) Detail of cingulum; cingulum ends in an obtuse straight line, SEM. (H) Details of Fig. 3E loculate areolae, SEM. Scale bars represent: A, $100 \mu \mathrm{m} ; \mathrm{B} \& \mathrm{C}, 20 \mu \mathrm{m} ; \mathrm{D}, 50 \mu \mathrm{m} ; \mathrm{E} \& \mathrm{G}, 10 \mu \mathrm{m} ; \mathrm{F}, 0.5 \mu \mathrm{m} ; \mathrm{H}, 2 \mu \mathrm{m}$. 
Cells are solitary, large, bilaterally symmetrical, 108.3$190.6 \mu \mathrm{m}$ in diameter, $413.3 \mu \mathrm{m}$ long, elliptical in cross section, crescent shaped in lateral view and of sigmoid form in ventro-dorsal view. Valve is conoidal with a rounded or truncated apex and with longitudinal undulations. Process is a cylindrical external tube, straightened towards the distal part, merging with the calyptra structure and circular pore in the distal part of the tip, 6.7-7.3 $\mu \mathrm{m}$ long, $0.8-1.0 \mu \mathrm{m}$ in diameter. Valve areolae, $13-16$ in $10 \mu \mathrm{m}$, are arranged in regularly straight striations, with a secondary quincuncial pattern. Otaria, claspers, and contiguous areas are absent. Girdle segments are oriented in a straight line and arranged in two dorsiventral columns. Segment areolae, 17-22 in $10 \mu \mathrm{m}$, are arranged in regular, straight striations, with a secondary quincuncial pattern, loculate areolae, with the velum perforated by slit-like pores and internal foramina, circular to subcircular. Horizontal axis and perpendicular axis of segments are 108.3-190.6 and 11.7-25.0 $\mu \mathrm{m}$ in length, respectively.

Distribution. Neocalyptrella robusta is distributed from tropical to temperate waters (Hasle and Syvertsen 1996, Hernández-Becerril and Meave del Castillo 1996). It has been reported to occur in littoral Argentinean waters (Ferrario and Galávan 1989, as Rhizosolenia robusta). During this study, N. robusta was rare but observed in September 2008 and June 2009 at Geoje Island, the Korea Straight, the Wolsung coast, and the Yellow Sea.

\section{Pseudosolenia calcar-avis (Schultze) Sundström 1986 (Fig. 4, A-H)}

Schultze 1858, p. 339, Pl. 13, Figs 5-10; Peragallo 1892, p. 113, Pl. 17, Fig. 9; Hustedt 1930, p. 592, Fig. 339 as R. calcar-avis; Cupp 1943, p. 89, Fig. 51 as R. calar-avis; Navarro 1981, p. 430, Figs 36 \& 37 as R. calcar-avis; Sundström 1986, p. 95, Figs 40-46 \& 247-257; Hernández-Becerril 1995, p. 254, Figs 7-10; Hasle and Syvertsen 1996, p. 160, Pl. 30; Sunesen and Sar 2007, p. 637, Figs 68-81.

Synonym. Rhizosolenia calcar-avis Schultze 1858.

Cells are usually solitary, elongated, of cylinder shape, bilaterally symmetrical, circular in cross section, 9.3-90.0 $\mu \mathrm{m}$ in diameter, 206.7-793.8 $\mu \mathrm{m}$ long. Valve is sub-conical, asymmetrical, with the ventral part slightly longer than the dorsal part. Contiguous area is a narrow groove, sigmoid, extended from the basal part of the process to the margin in the ventral part of the valve. Process is claw or screw shaped, slightly or strongly curved, and tapered towards the distal part, 10.7-51.4 $\mu \mathrm{m}$ long. Otaria and claspers are absent. Valve areolae are poroid, circular, 16-34 in $10 \mu \mathrm{m}$. Striations are regular and straight, with a secondary quincuncial pattern. Girdle segments are scale-shaped to rhomboidal, arranged in two or multiples of two columns, with a sub marginal seam-like structure close to the advalvar margin with entire hyaline edges. Horizontal axis and perpendicular axis of segments are 9.3-90.0 and 9.3-46.2 $\mu \mathrm{m}$ long, respectively. Segmented areolae are $21-38$ in $10 \mu \mathrm{m}$ in a secondary quincuncial pattern.

Distribution. Pseudosolenia calcar-avis is a circumglobally distributed species (Sundström 1986) and occurs in warm waters and occasionally in temperate waters (Hasle and Syvertsen 1996). It has been reported several times in both oceanic and near-shore waters along the coastline of Argentina (Ferrario and Galávan 1989, as Rhizosolenia calcar-avis). In the present study, this species was rarely observed in September 2008 to September 2009 in the oceanic waters of Jeju Island and the Yellow Sea.

\section{Guinardia delicatula (Cleve) Hasle 1995 (Fig. 5, A \& B)}

Cleve 1900, p. 28, Fig. 11; Hustedt 1930, p. 577, Fig. 328; Cupp 1943, p. 83, Fig. 44; Hendey 1964, p. 147, Pl. 4, Fig. 2; Drebes 1974, p. 49, Fig. 35a; Sundström 1986, p. 103, Figs $272 \& 273$.

Basionym. Rhizosolenia delicatula Cleve 1900.

Cells form fairly straight chains and are bilaterally symmetrical. Cells are 7.9-13.2 $\mu \mathrm{m}$ in diameter, 24.9-30.0 $\mu \mathrm{m}$ in length. Valve margins are round. External process is thin and short, and narrow, tube-shaped, and oblique to the pervalvar axis. External processes are 2.1-5.0 $\mu \mathrm{m}$ long. External process fits into a depression on the adjacent valve. Girdle segments are composed of open bands, with poroid areolae, and are not noticeable. Segment horizontal axes are 7.9-13.2 $\mu \mathrm{m}$ long.

Distribution. Hasle and Syvertsen (1996) reported that G. delicatula is a cosmopolitan species in temperate and tropical waters. During the present study, this species was recorded in July 2009 and January 2010 in the coastal waters of Sacheon, Incheon, and Mokpo.

\section{Guinardia flaccida (Castracane) H. Peragallo 1892 (Fig. 5, C-E)}

Castracane 1886, p. 74, Pl. 29, Fig. 4; Peragallo 1892, p. 107, Pl. 1, Figs 3-5; Bergon 1903, p. 78, Pl. 2, Figs 1-3; Hustedt 1930, p. 562, Fig. 322; Cupp 1943, p. 78, Fig. 40; Hendey 1964, p. 147, Pl. 5, Fig. 5; Drebes 1974, p. 58, Fig. 43a; Hasle 1975, p. 116, Figs 64, 65 \& 81-89; Navarro 1981, 

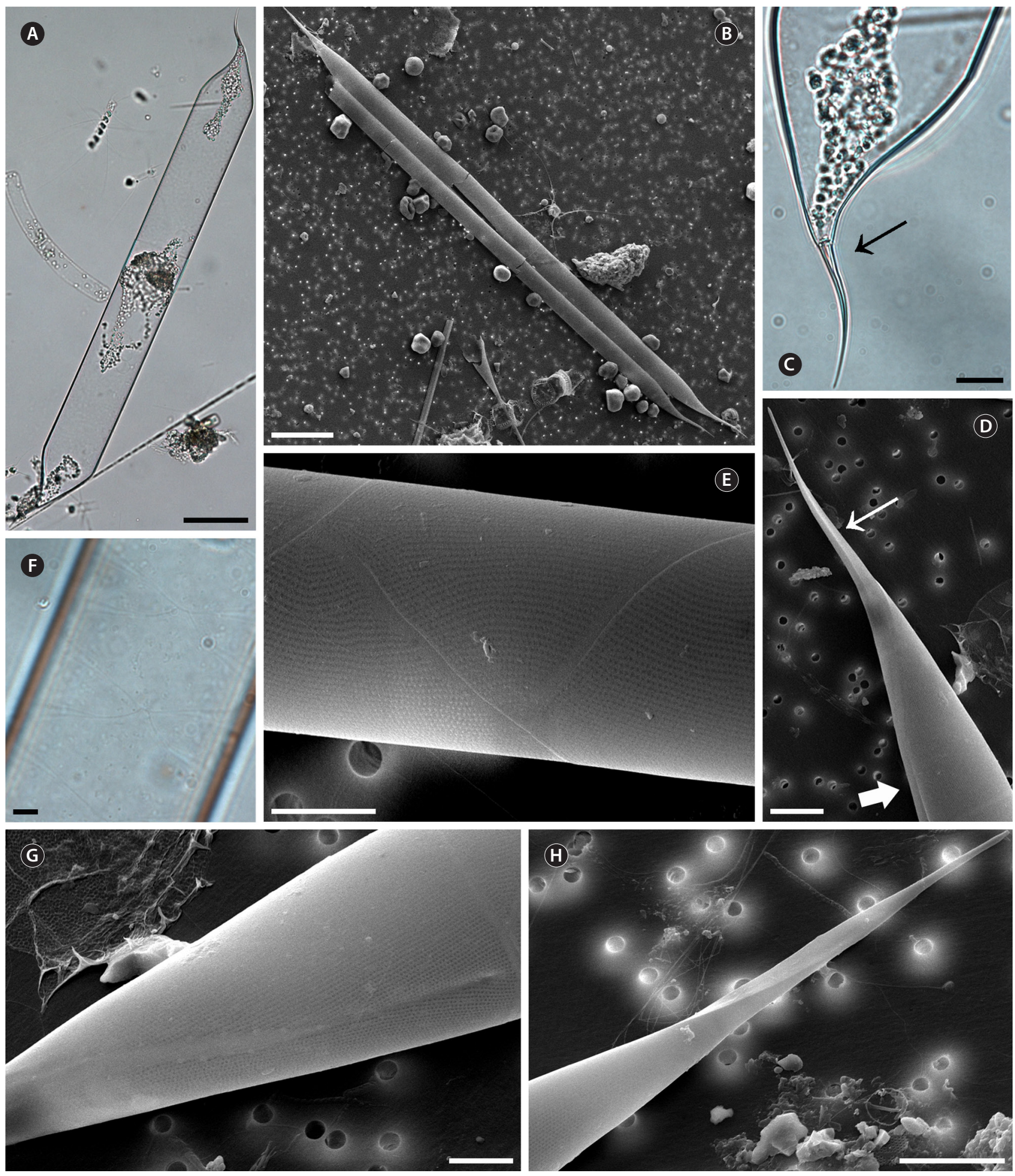

Fig. 4. Pseudosolenia calcar-avis. (A) A complete cell, light microscopy (LM). (B) Complete cells, scanning electron microcopy (SEM). (C) Apical part of valve, internal structure of external process (arrow), LM. (D) Apical part of valve, claw or screw shaped external process (arrow), SEM. (E) Details of girdle segments, regularly straight striation, SEM. (F) Girdle segments, LM. (G) Apical part of valve, sigmoid contiguous area, SEM. (H) Screw shaped external process, SEM. Scale bars represent: A \& B, $50 \mu \mathrm{m} ; \mathrm{C}-\mathrm{E} \& \mathrm{H}, 10 \mu \mathrm{m} ; \mathrm{F} \& \mathrm{G}, 5 \mu \mathrm{m}$. 

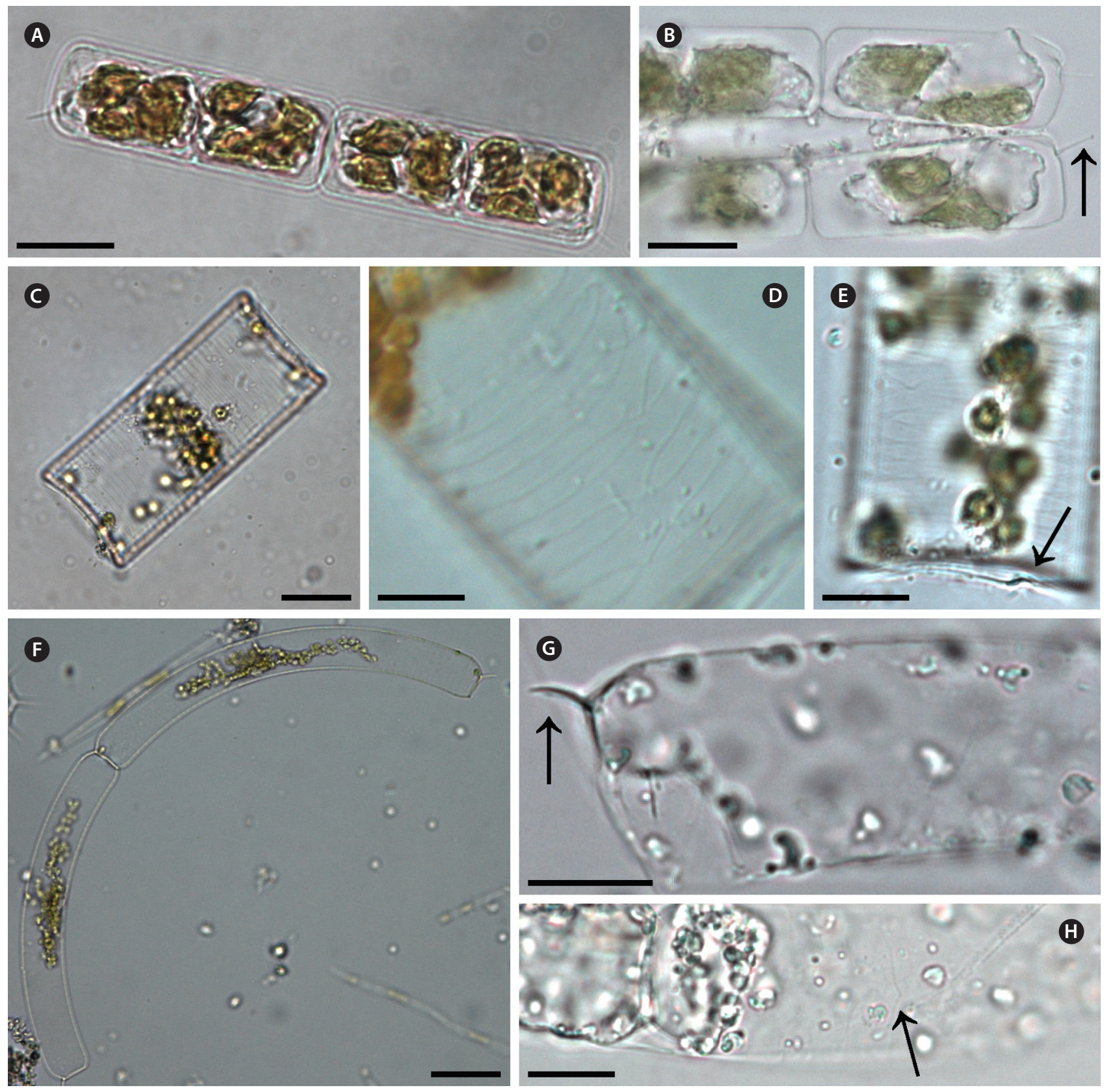

Fig. 5. Guinardia delicatula. (A) Chain formed four cells, light microscopy (LM). (B) External process in valve marginal part (arrow), LM. (C-E) Guinardia flaccid. (C) A complete cells, LM. (D) Detail of girdle segments, LM. (E) Apical part of valve (arrow), LM. (F-H) Guinardia striata. (F) Chain formed two cells, LM. (G) External part of process, LM. (H) Girdle bands (arrow), LM. Scale bars represent: A-E, G \& H, $10 \mu \mathrm{m} ; \mathrm{F}, 20 \mu \mathrm{m}$.

p. 430, Figs 31 \& 32; Takano 1990, pp. 260-261.

Basionym. Rhizosolenia flaccida Castracane 1886.

Cells are solitary or form fairly straight chains, and are bilaterally symmetrical. Cells are $14.0-42.5 \mu \mathrm{m}$ in diameter, 50.0-125.0 $\mu \mathrm{m}$ in length. Valves are flat or slightly concave. External processes are short and tube-shaped. Short tube-shaped external processes are located on the external valve surface. External processes are 1.5-1.8 $\mu \mathrm{m}$ long.
Girdle segments composed of open bands with poroid areolae. The segment horizontal axis and perpendicular axis are 14.0-42.5 and 1.3-5.0 $\mu \mathrm{m}$ in length, respectively.

Distribution. Guinardia flaccida shows a cosmopolitan distribution except the two polar bodies of water (Hasle and Syvertsen 1996). During the present study, G. flaccida was frequently observed in September 2008 and August 2009 in the coastal waters of the Yellow Sea, Geoje 
Island, Namhae, Sacheon, Tongyeang, and Incheon.

\section{Guinardia striata (Stolterforth) Hasle 1995 (Fig. 5, F-H)}

Stolterforth 1879, p. 836, Fig. a \& b; Peragallo 1888, p. 82, Pl. 6, Fig. 44; Peragallo 1892, p. 108, Pl. 13, Figs 17 \& 18; Bergon 1903, p. 57, Pl. 1, Figs 1-8; Hustedt 1920, Pl. 320, Figs 4 \& 5; Hustedt 1930, p. 578, Fig. 329; Cupp 1943, p. 83, Fig. 45; Hendey 1964, p. 148, Pl. 4, Fig. 5; Drebes 1974, p. 49, Fig. 35b; Hasle 1975, p. 113, Figs 66-73; Sundström 1980, p. 580, Figs 2-4; Navarro 1981, p. 430, Fig. 48 as $R$. stolterforthii; Sundström 1986, p. 103, Figs 274 \& 275; Von Stosch 1986, p. 319, Figs 13 \& 14; Hernández-Becerril 1995, p. 262, Figs 53-56.

Basionym. Rhizosolenia stolterforthii (Stolterforth) $\mathrm{H}$. Peragallo 1888.

Cells form curved chains, rarely spiraling chains, and are bilaterally symmetrical. Cells are 10.0-20.0 $\mu \mathrm{m}$ in diameter, and 50.0-120.0 $\mu \mathrm{m}$ in length. Valve flat and rounded at margin. External processes are thin, and hook-shaped to the pervalvar axis, and the external processes are 4.3-6.7 $\mu \mathrm{m}$ long. External process fits into a depression on the adjacent valve. Girdle bands composed of open bands with poroid areolae. Segment horizontal axis and perpendicular axis are 10.0-20.0 and 4.3-4.6 $\mu \mathrm{m}$ long, respectively.

Distribution. Guinardia striata is cosmopolitan, but it does not occur in polar bodies of water (Hasle and Syvertsen 1996). During the present study, G. striata was rarely observed in September 2008 and August 2009 in the coastal waters of Namhae, Daebu Island, Incheon, and Yeongdeok.

\section{Dactyliosolen fragilissimus (Bergon) Hasle 1995 (Fig. 6, A-D)}

Bergon 1903, p. 49, Pl. 1, Figs 9 \& 10; Hustedt 1930, p. 571, Fig. 324; Cupp 1943, p. 80, Fig. 41; Drebes 1974, p. 48, Fig. 34b \& c; Hasle 1975, p. 114, Figs 61, 62 \& 74-78; Navarro 1981, p. 430, Fig. 38 as R. fragilissima; Sundström 1986, p. 103, Figs 268 \& 269; Takano 1990, pp. 262-263.

Basionym. Rhizosolenia fragilissima Bergon 1903.

Cells are cylindrical with rounded marginal parts, forming straight chains. Cells are connected in loose fitting chains at the center of the valve surface. Cells are 8.3$20.0 \mu \mathrm{m}$ in diameter, and 25.0-33.4 $\mu \mathrm{m}$ in length. Valves are flat or convex at the central part. External process is a thin, oblique tube in the central part of the valve. External processes are 1.1-4.3 $\mu \mathrm{m}$ long and fit into a depression on adjacent cells. Girdle bands composed of half bands with poroid areolae.

Distribution. Dactyliosolen fragilissimus is probably cosmopolitan (Hasle and Syvertsen 1996) but was rarely observed in February 2010 in Goseong.

Remarks. Cell length of Dactyliosolen fragilissimus varies from 30.0-80.0 $\mu \mathrm{m}$ (Gran and Angst 1931), 50.0-80.0 $\mu \mathrm{m}$ (Cupp 1943), 42.0-67.0 $\mu \mathrm{m}$ (Hendey 1964), and 42.0$300.0 \mu \mathrm{m}$ (Hasle and Syvertsen 1996). During this study, $D$. fragilissimus was not observed with a length of pervalvar axis up to $100 \mu \mathrm{m}$.

\section{Dactyliosolen phuketensis (Sundström) Hasle 1995 (Fig. 6, E-G)}

Sundström 1980, p. 579, Figs 1-3; Sundström 1986, p. 103, Figs 270 \& 271; Von Stosch 1986, p. 323, Figs 15-17; Hernández-Becerril 1995, p. 262, Figs 50-52.

Basionym. Rhizosolenia phuketensis Sundström 1980.

Cells are cylindrical with a rounded marginal part, forming curved chains. Cells are connected in fairly fitting chains and are bilaterally symmetrical. Cells are 10.0-20.0 $\mu \mathrm{m}$ in diameter, and 31.3-129.2 $\mu \mathrm{m}$ long. Valves are flat or slightly convex. External process is usually an obtuse, short tube in the valve marginal part. External processes are 1.3-6.7 $\mu \mathrm{m}$ long and fit into a depression in adjacent cells. Girdle bands are composed of half bands with poroid areolae. Segment horizontal axis and perpendicular axis are 10.0-20.0 and 1.3-6.6 $\mu \mathrm{m}$ in length, respectively.

Distribution. Sundström (1986) reported that $D$. phuketensis occurs in warm water regions to temperate regions including the North Sea and Skagerrak. During this study, D. phuketensis was newly recorded in June 2009 and October 2009 from the coastal waters of Geoje Island, Sacheon, Tongyeang, Yeongduk, and the Yellow Sea.

Remarks. Dactyliosolen phuketensis was recorded for the first time in Korean coastal waters, but this species was already observed a long time ago, resembling G. striata. Although the two species belonged to different genera and were recorded in Korean coastal waters, they can be easily misidentified using the curved cell and colony shape as discriminating characters. The external process shapes are different between two taxa. The external processes of G. striata are hook shaped, whereas those of $D$. phuketensis are short external tubes. The position of the external process is not the same, and segment (band) shape also differs. Representatives of the genus Guinardia are composed of an open band, but the genus Dactyliosolen is composed of a half band. 

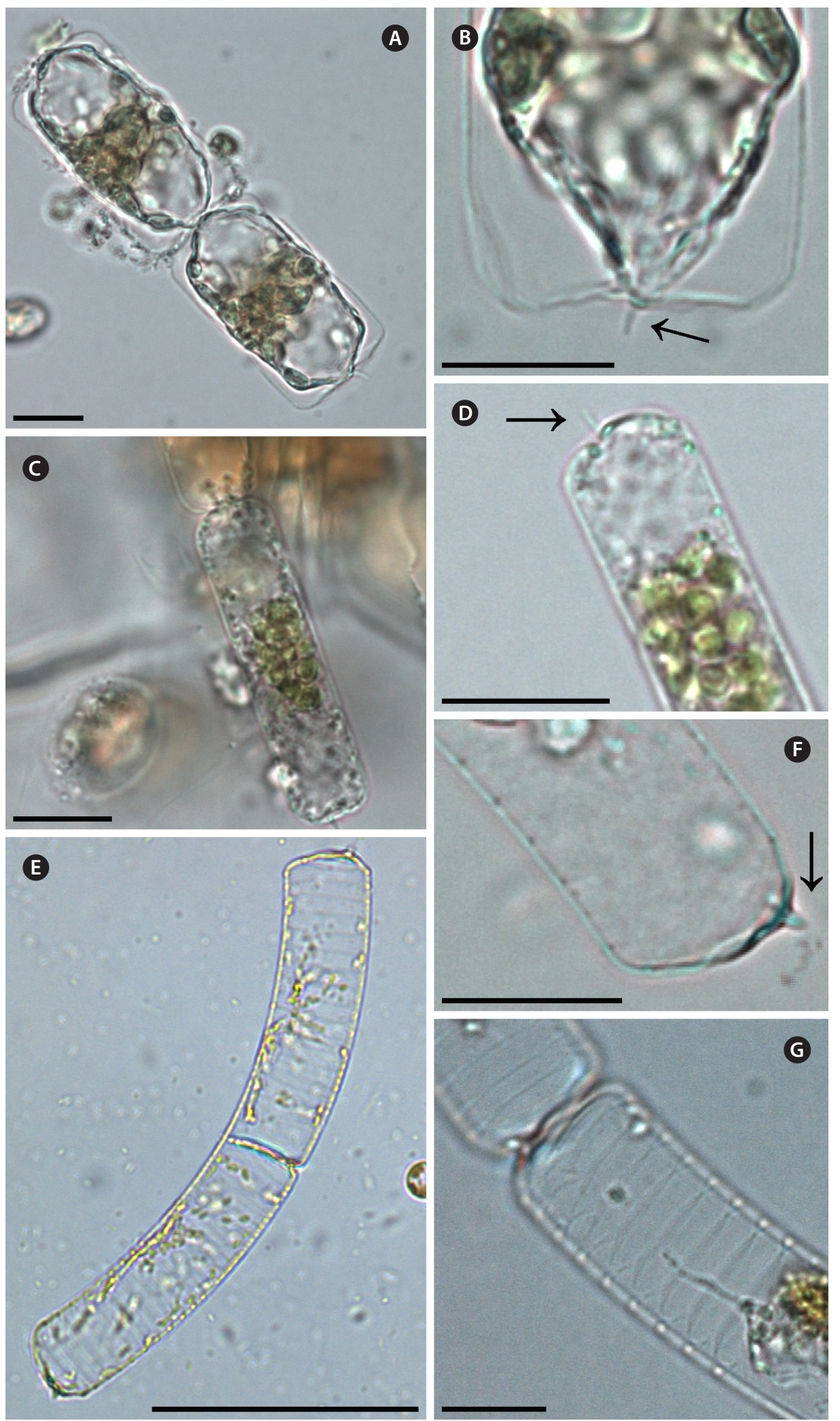

Fig. 6. Dactyliosolen fragilissimus. (A) Chain formed two cells, light microscopy (LM). (B) Detail of external process in valve apex (arrow), LM. (C) Chain formed two cells, LM. (D) Detail of external process in valve apex (arrow), LM. (E-G) Dactyliosolen phuketensis. (E) Chain formed two cells, LM. (F) Apical part of valve, external process in valve marginal, LM. (G) Detailed girdle bands, half band, LM. Scale bars represent: A-D, F \& G, $10 \mu \mathrm{m} ; \mathrm{E}, 50 \mu \mathrm{m}$. 


\section{DISCUSSION}

The family Rhizosoleniaceae includes Rhizosolenia, Proboscia, Pseudosolenia, Neocalyptrella, Guinardia, Dactyliosolen, and Urosolenia. The key morphological characters of the family Rhizosoleniaceae are cylindrical cells in solitary or chain form, unipolar and symmetrical valves, numerous chloroplasts, and a few resting spores. The genera within Rhizosoleniaceae are very common in the marine ecosystem and sometimes dominate the phytoplankton biomass in highly productive oceanic regions (Sundström 1986, Hernández-Becerril and Meave del Castillo 1996, 1997). Some species of the family Rhizosoleniaceae are causative bloom organisms in various regions of the world (Jordan and Priddle 1991, Jordan et al. 1991, Takahashi et al. 1994). These species are very important diatoms in marine environments.

As shown in Table 2 of Yun and Lee (2010), Table 2 in Yun et al. (2011), and Tables 2-4 in the present study, we divided the 6 genera within the family Rhizosoleniaceae into two groups by morphological diagnostic characteristics including the shape of the external process and girdle segments in the column (Yun and Lee 2010, Yun et al. 2011). The first group had a conoidal valve and loculate areolae and was comprised of Proboscia, Pseudosolenia, Rhizosolenia, Neocalyptrella, and the second group had a flat or rounded valve and poroid areolae and was of Guinardia and Dactyliosolen. In the present study, 2 species belonged to Proboscia, 3 species to Guinardia, 2 species to Dactyliosolen, 1 species to Pseudosolenia, and 1 species belonged to Neocalyptrella.

Cell diameters of Proboscia alata were 3.3-13.3 $\mu \mathrm{m}$, but previous studies reported 7.0-18.0 $\mu \mathrm{m}$ (Cupp 1943 as Rhizosolenia alata), 8.5-11.5 $\mu \mathrm{m}$ (Sundström 1986), 2.5-42.0 $\mu \mathrm{m}$ (Jordan et al. 1991), 7.0-24.0 $\mu \mathrm{m}$ (Hernández-Becerril 1995), 2.5-13.0 $\mu \mathrm{m}$ (Hasle and Syvertsen 1996), and 7.0$11.0 \mu \mathrm{m}$ (Sunesen and Sar 2007). Cell diameters of P. indi$c a$ were 25.0-125.0 $\mu \mathrm{m}$. Our specimens closely resembled those described previously (Cupp 1943, HernándezBecerril 1995, Jordan and Ligowski 2004), but their cell diameters were smaller $(16.0-73.0 \mu \mathrm{m})$ than those of our specimens. Cell diameters of $N$. robusta $(108.3-190.6 \mu \mathrm{m})$ and P. calcar-avis (9.3-90.0 $\mu \mathrm{m})$ were smaller than those of Hasle and Syvertsen (1996) and Sunesen and Sar (2007), respectively.

Cell diameters of G. delicatula were 7.9-13.2 $\mu \mathrm{m}, \mathrm{G}$. flaccida were 23.3-42.5 $\mu \mathrm{m}$, and G. striata were 10.0-20.0 $\mu \mathrm{m}$. No differences were observed in the 3 species cell diameters compared with those of many studies (Cupp 1943, Hernández-Becerril 1995, Hasle and Syvertsen 1996).
Cell diameters of $D$. fragilissimus and $D$. phuketensis were $8.3-20.0 \mu \mathrm{m}$ and $10.0-20.0 \mu \mathrm{m}$, respectively. Our specimens were similar to those of Hasle and Syvertsen (1996), but their cell diameters were wider than those of our specimens.

External processes varied from short tube-shaped in $N$. robusta and D. phuketensis, claw or screw-shaped in P. calcar-avis, narrow tube-shaped in G. delicatula, slight hook-shaped in G. striata, and oblique tube-shaped in D. fragilissimus. The genus Proboscia was distinguished within the first group because the external processes were longer, and the valve was changed to a probosic structure. As the external process of Rhizosolenia was in the shape of a needle and tube, this genus is separated from other genera (Yun and Lee 2010, Yun et al. 2011). The external process of the family Rhizosoleniaceae is an important taxonomic key character.

Areolae occurred in various forms on the external view; circular to sub circular pore-shaped in P. alata, P. indica, and $N$. robusta and circular to slightly oval pore-shaped in Pseudosolenia calcar-avis. We were unable to count the number of areolae in G. delicatula, G. striata, D. fragilissimus, and D. phuketensis, but areolae of D. phuketensis are slit-like with a parallel to pervalvar axis (HernándezBecerril 1995).

The number of areolae in the valves varied from 52-90 in $10 \mu \mathrm{m}$ in $P$. alata, 30-60 in $10 \mu \mathrm{m}$ in P. indica, $13-16$ in $10 \mu \mathrm{m}$ in N. robusta, and 16-34 in $10 \mu \mathrm{m}$ in P. calcar-avis. Hasle and Syvertsen (1996) reported that $N$. robusta (as Rhizosolenia robusta) had 19-20 in $10 \mu \mathrm{m}$ and 28-32 in 10 $\mu \mathrm{m}$ in P. calcar-avis. Sunesen and Sar (2007) reported that P. alata had 54 in $10 \mu \mathrm{m}, 17$ in $10 \mu \mathrm{m}$ in N. robusta, and 2332 in $10 \mu \mathrm{m}$ in P. calcar-avis. No differences were observed from previous reports. The number of areolae in the segments varied from 25-62 in $10 \mu \mathrm{m}$ in P. alata, 17-22 in 10 $\mu \mathrm{m}$ in $N$. robusta, and 21-38 in $10 \mu \mathrm{m}$ in P. calcar-avis. $N$. robusta has 24-26 in $10 \mu \mathrm{m}$ (Hasle and Syvertsen 1996 as Rhizosolenia robusta), 22-23 in $10 \mu \mathrm{m}$ in $N$. robusta, and 28-32 in $10 \mu \mathrm{m}$ in P. calcar-avis (Sunesen and Sar 2007). Our specimens had a similar number of areolae in the segments compared with those of previous reports. We could not count number of areolae in P. indica, G. delicatula, G. flaccida, G. striata, D. fragilissimus, and D. phuketensis, because of delicate cells.

Abundant distributions of G. flaccida and P. indica were found in Korean coastal waters. G. flaccida was widely distributed at 6 stations, and D. fragilissimus and $N$. robusta were sporadically found at 4 stations in Korean coastal waters. P. calcar-avis has been frequently found in the Korean coastal waters, and this species is a warm 
and temperate water species (Cupp 1943, Hendey 1964, Sundström 1986, Hernández-Becerril 1995, Hasle and Syvertsen 1996). Dactyliosolen phuketensis was new to Korean coastal waters.

\section{ACKNOWLEDGEMENTS}

This research was supported by Sangmyung University in 2009. We would like to thank Prof. Hans-U. Dahms of the Department of Life Science, Sangmyung University for critical comments on an earlier manuscript draft and language improvements.

\section{REFERENCES}

Anonymous. 1975. Proposals for a standardization of diatom terminology and diagnoses. Nova Hedwigia Beih. 53:323-354.

Balech, E. 1964. El plancton de Mar del Plata durante el período 1961-62 (Buenos Aires, Argentina). Bol. Inst. Biol. Mar. Mar del Plata 7:1-49.

Balech, E. 1971. Microplancton de la campaña oceanográfica Productividad III. Revista del Museo Argentino de Ciencìas Naturales 'Bernardino Rivadavia' e Instituto Nacional de Investigación de las Ciencias Naturales. Hidrobiologia 3:1-202.

Balech, E. 1979. Dinoflagelados. Campaña Oceanográfica Argentina Islas Orcadas, 06/75. Servicio de Hidrografía Naval (Buenos Aires) H 655:1-76.

Bergon, P. 1903. Études sur la flore diatomique du bassin d'Arcachon et des parages de l' Atlantique voisins de cette station. Bull. Soc. Sci. Arcachon 6:39-113.

Brightwell, T. 1858. Remarks on the genus "Rhizosolenia" of Ehrenberg. Q. J. Microsc. Sci. 6:93-95.

Castracane, F. 1886. Report on the Diatomaceae collected by H.M.S. Challenger during the years 1873-1876. Report of the Scientific Results of the Voyage of H.M.S. Challenger 1873-1876, Botany 2:1-178.

Chang, M. \& Shim, J. H. 1993. A study on the phytoplankton of the Yellow Sea in Autumn, 1984. Ocean Res. 15:15-28.

Cleve, P. T. 1900. The plankton of the North Sea, the English Channel, and the Skagerak in 1898. K. Svenska Vet. Akad. Handl. 32:1-53.

Cupp, E. E. 1943. Marine plankton diatoms of the west coast of North America. Bull. Scripps Inst. Oceanogr. Univ. Calif. 5:1-238.

De Toni, G. B. 1890. Osservazioni sulla tassonomia delle Bacillariee (Diatomee): sequita da un prospetto dei generi delle medesime. Notarisia 5:885-922.

Drebes, C. G. 1974. Marines phytoplankton: eine Ausw. d. Helgoläner plankton (Diatomeen, Perideneen). Thieme, Stuttgart, $186 \mathrm{pp}$.

Edlund, M. B. \& Stoermer, E. F. 1993. Resting spores of the freshwater diatoms Acanthoceras and Urosolenia. J. Paleolimnol. 9:55-61.

Ferrario, M. E. \& Galávan, N. M. 1989. Catálogo de las diatomeas marinas citadas entre los $36^{\circ}$ y los $60^{\circ} \mathrm{S}$ con especial referencia al Mar Argentino. Publ. Inst. Antárt. Argent. 20:1-327.

Gómez, F. \& Souissi, S. 2007. Unusual diatoms linked to climatic events in the northeastern English Channel. J. Sea Res. 58:283-290.

Gran, H. H. 1905. Diatomeen. In Brandt, K. \& Apstein, C. (Eds.) Nordisches Plankton: Botanischer Teil. Vol. 19. Lipsius and Tischer, Kiel and Leipzig, pp. 1-146.

Gran, H. H. \& Angst, E. C. 1931. Plankton diatoms of Puget Sound. Publ. Puget Sound Biol. Stn. 7:417-519.

Hasle, G. R. 1975. Some living marine species of the diatom family Rhizosoleniaceae. Nova Hedwigia Beih. 53:99153.

Hasle, G. R. \& Fryxell, G. A. 1970. Diatoms: cleaning and mounting for light and electron microscopy. Trans. Am. Microsc. Soc. 89:469-474.

Hasle, G. R. \& Syvertsen, E. E. 1996. Marine diatoms. In Tomas, C. R. (Ed.) Identifying Marine Diatoms and Dinoflagellates. Academic Press, San Diego, CA, pp. 5-385.

Hendey, N. I. 1964. An introductory account of the smaller algae of British coastal waters. Part 5: Bacillariophyceae (Diatoms). Her Majesty's Stationery Office, London, 317 pp.

Hernández-Becerril, D. U. 1995. Planktonic diatoms from the Gulf of California and coasts off Baja California: the genera Rhizosolenia, Proboscia, Pseudosolenia, and former Rhizosolenia species. Diatom Res. 10:251-267.

Hernández-Becerril, D. U. \& Meave del Castillo, M. E. 1996. The marine planktonic diatom Rhizosolenia robusta (Bacillariophyta): morphological studies support its transfer to a new genus, Calyptrella gen. nov. Phycologia 35:198-203.

Hernández-Becerril, D. U. \& Meave del Castillo, M. E. 1997. Neocalyptrella, gen, nov., a new name to replace Calyptrella Hernández-Becerril et Meave. Phycologia 36:329.

Hustedt, F. 1920. Atlas der Diatomaceenkunde. In Schmidt, A. (Ed.) Atlas der Diatomaceen-kunde. O. R. Reisland, Leipzig, pp. 317-320.

Hustedt, F. 1930. Die Kieselalgen Deutschlands, Österrreichs und der Schweiz mit Berückichtigung der übrigen Länder Europas sowie der angrenzende Meeresgebiete. In 
Rabenhorst, L. (Ed.) Kryptogamen-Flora von Deutschland, Österreich und der Schweiz. Akademische Verlagsgesellschaft m. b. H., Leipzig, pp. 1-920.

Jordan, R. W. \& Ito, R. 2002. Observations on Proboscia species from Late Cretaceous sediments, and their possible evolution from Kreagra. In John, J. (Ed.) Proc. 15th Int. Diatom Symp., A.R.G. Ganlner Verlag K. G., Ruggell, pp. 313-329.

Jordan, R. W. \& Ligowski, R. 2004. New observations on Proboscia auxospores, and validation of the family Probosciaceae fam. nov. Vie et Milieu 54:91-103.

Jordan, R. W. \& Ligowski, R. 2006. Observations on the auxospores, initial cells and vegetative cells of Proboscia truncata (Bacillariophyta). Nova Hedwigia Beih. 130:201-212.

Jordan, R. W., Ligowski, R., Nöthig, E. -M. \& Priddle, J. 1991. The diatom genus Proboscia in Antarctic waters. Diatom Res. 6:63-78.

Jordan, R. W. \& Priddle, J. 1991. Fossil members of the diatom genus Proboscia. Diatom Res. 6:55-61.

Jordan, R. W. \& Saito, M. 1999. The genus Proboscia from the Thalassiosira yabei Zone (Middle-Late Miocene) sediments of Hokkaido, Japan. In Mayama, S., Idei, M. \& Koizumi, I. (Eds.) Proc. 14th Int. Diatom Symp., Koeltz Scientific Books, Koenigstein, pp. 565-580.

Kim, S. W., Lee, J. H. \& Hong, W. H. 1993. Marine environment on the view-point of plankton dynamics in coastal waters adjacent to Samcheonpo Thermal Power Plant, Korea. Collected Thesis, Yongin Univ. 9:357-372.

Lange, K. B. 1985. Spatial and seasonal variations of diatom assemblages off the Argentinian coast (South Western Atlantic). Oceanol. Acta 8:361-369.

Lee, J. H. 1995. Additional check-list of marine planktonic algae in the coastal waters of Korea. I. Bacillariophyceae. J. Nat. Sci. Sangmyung Women's Univ. 2:71-198.

Li, Y., Cen, J. -Y., Qi, Y. -Z. \& Lü, S. -H. 2009. Morphological features observations of Urosolenia in Chinese freshwaters. Acta Hydrobiol. Sin. 33:566-570.

Marques Da Cunha, A. \& Da Fonseca, O. 1917. O microplancton do Atlantico nas imediações de Mar del Plata. Mem. Inst. Oswaldo Cruz 9:140-142.

Moon, C. -H. \& Choi, H. -J. 1991. Studies on the environmental characteristics and phytoplankton community in the Nakdong River estuary. J. Oceanol. Soc. Korea 26:144154.

Moreno, J. L., Licea, S. \& Santoyo, H. 1996. Diatomeas del Golfo de California. Universidad Autonóma de Baja California Sur, Loreto, $275 \mathrm{pp}$.

Navarro, J. N. 1981. A survey of the marine diatoms of Puerto Rico. I. Suborders Coscinodiscineae and Rhizosoleni- ineae. Bot. Mar. 24:427-439.

Okuno, H. 1952. Electron microscopical study on antarctic diatoms (3). J. Jpn. Bot. 27:347-356.

Okuno, H. 1957. Electron microscopical study on fine structures of diatom frustules. XV. Observations on the genus Rhizosolenia. Bot. Mag. Tokyo 70:101-107.

Okuno, H. 1960. Electron microscopical study on fine structures of diatom frustules. XVIII. Bot. Mag. Tokyo 73:310316.

Okuno, H. 1968. Electron microscopical study on fine structures of diatom frustules. XX. Observations on genus Rhizosolenia. Bot. Mag. Tokyo 81:79-88.

Peragallo, H. 1888. Diatomées de la baie de Villefranche. Bull. Soc. Hist. Nat. Toulouse 22:1-100.

Peragallo, H. 1892. Monographie du genre Rhizosolenia et de quelques genres voisins. Diatomiste 1:1-39.

Pritchard, A. 1861. A history of infusoria, including the Desmidiaceae and Diatomaceae, British and foreign. 4 th ed. Whittaker, London, 968 pp.

Ross, R., Cox, E. J., Karayeva, N. I., Mann, D. G., Paddock, T. B. B., Simonsen, R. \& Sims, P. A. 1979. An amended terminology for the siliceous components of the diatom cell. Nova Hedwigia Beih. 64:513-533.

Rott, E., Kling, H. \& McGregor, G. 2006. Studies on the diatom Urosolenia Round \& Crawford (Rhizosoleniophycideae) part I. New and reclassified species from subtropical and tropical freshwaters. Diatom Res. 21:105-124.

Round, F. E., Crawford, R. M. \& Mann, D. G. 1990. The diatoms: biology and morphology of the genera. Cambridge University Press, London, 747 pp.

Schultze, M. 1858. Innere Bewegungserscheinungen bei Diatomeen der Nordsee aus den Gattungen Coscinodiscus, Denticella, Rhizosolenia. Arch. Anat. Physiol. Wiss. Med. 1858:330-342.

Shim, J. H. 1994. Illustrated encyclopedia offauna and flora of Korea, vol. 34 Marine phytoplankton. Ministry of Education, Seoul, $487 \mathrm{pp}$.

Simonsen, R. 1974. The diatom plankton of the Indian Ocean Expedition of R/V “Meteor” 1964-1965. Meteor Forsch. Ergeb. Reihe D. 19:1-107.

Simonsen, R. 1979. The diatom system: ideas on phylogeny. Bacillaria 2:9-71.

Stolterforth, H. 1879. On a new species of the genus Eucampia. J. R. Microsc. Soc. 2:835-836.

Sundström, B. G. 1980. Rhizosolenia phuketensis sp. nov. and Rhizosolenia stolterforthii H. Peragallo (Bacillariophyceae). Bot. Not. 133:579-583.

Sundström, B. G. 1986. The marine diatom genus Rhizosolenia: a new approach to the taxonomy. Ph.D. dissertation, Lund University, Lund, Sweden, 117 pp. 
Sunesen, I. \& Sar, E. A. 2007. Marine diatoms from Buenos Aires coastal waters (Argentina). IV. Rhizosolenia s. str., Neocalyptrella, Pseudosolenia, Proboscia. Phycologia 46:628-643.

Takahashi, K., Jordan, R. \& Priddle, J. 1994. The diatom genus Proboscia in subarctic waters. Diatom Res. 9:411-428.

Takano, H. 1990. Diatoms. In Fukuyo, Y., Takano, H., Chihara, M. \& Matsouka, K. (Eds.) Red Tide Organisms in Japan: An Illustrated Taxonomic Guide. Uchida Rokakuho, Tokyo, pp. 162-331.

Von Stosch, H. A. 1986. Some marine diatoms from the Australina region, especially from Port Phillip Bay and tropical north-eastern Australia. Brunonia 8:293-348.

Yun, S. M. \& Lee, J. H. 2010. Morphology and distribution of some marine diatoms, family Rhizosoleniaceae, in Korean coastal waters: a genus Rhizosolenia 1. Algae 25:173-182.
Yun, S. M. Lee, S. D. \& Lee, J. H. 2011. Morphology and distribution of some marine diatoms, family Rhizosoleniaceae, genus Rhizosolenia, in Korean coastal waters. Algae 26:141-152.

Yoon, Y. -H. \& Koh, N. -P. 1994. Distribution of phytoplankton population in the coastal waters of Keumo Islands, southern Korea in summer. Bull. Yosu Natl. Fish. Univ. 8:21-35.

Yoon, Y. -H. \& Koh, N. -P. 1995. Studies on the environmental characteristics of the breeding ground in the Kogumsudo, southern part of Korean Peninsula I. Seasonal succession of phytoplankton population. J. Aquac. 8:47-58.

Yoon, Y. H., Rho, H. K. \& Kim, Y. G. 1992. Seasonal succession of phytoplankton population in the Hamdok port, northern Cheju Island. Bull. Mar. Res. Inst. Cheju Natl. Univ. 16:27-42. 